Article

\title{
Evaluation of the Egg Bank of Two Small Himalayan Lakes
}

\author{
Roberta Piscia ${ }^{1, * \mathbb{C}}$, Sara Bovio ${ }^{2}$, Marina Manca ${ }^{1} \mathbb{D}$, Andrea Lami ${ }^{1}$ and Piero Guilizzoni ${ }^{1}$ \\ 1 CNR-IRSA, Largo Tonolli 50, 28922 Verbania (VB), Italy; marina.manca@irsa.cnr.it (M.M.); \\ andrea.lami@irsa.cnr.it (A.L.); piero.guilizzoni@irsa.cnr.it (P.G.) \\ 2 Independent Researcher, Via Rimembranza 12, 28043 Bellinzago Novarese (NO), Italy; sarabovio@gmail.com \\ * Correspondence: roberta.piscia@irsa.cnr.it
}

Received: 18 December 2019; Accepted: 6 February 2020; Published: 11 February 2020

check for updates

\begin{abstract}
High mountain lakes are biodiversity treasures. They host endemic taxa, adapted to live in extreme environments. Among adaptations, production of diapausing eggs allows for overcoming the cold season. These diapausing eggs can rest in the sediments, providing a biotic reservoir known as an egg bank. Here, we estimated changes in abundance of the egg bank in two lakes in the Khumbu Region of the Himalayas, during the last ca. 1100 and 500 years, respectively, by analyzing two sediment cores. We tested viability of the diapausing eggs extracted from different layers of the sediment cores under laboratory conditions. We found that only diapausing eggs of the Monogont rotifer Hexarthra bulgarica nepalensis were able to hatch, thus suggesting that a permanent egg bank is lacking for the other taxa of the lakes, not least for the two Daphnia species described from these sites. Our results confirm previous studies suggesting that in high mountain lakes, the production of diapausing is mainly devoted to seasonal recruitment, therefore leading to a nonpermanent egg bank. The different ability of different taxa to leave viable diapausing eggs in the sediments of high mountain lakes therefore poses serious constraints to capability of buffering risk of biodiversity loss in these extremely fragile environments.
\end{abstract}

Keywords: zooplankton; diapausing eggs; high mountain lakes; Himalayas

\section{Introduction}

High mountain lakes are highly vulnerable to impact of human activities and to climate change [1-3]. They host endemic populations of aquatic invertebrates, adapted to live under extreme environmental conditions using different mechanisms for optimizing life-cycles and growth during a very short ice-free period and under the ice cover $[3,4]$.

Research on high mountain crustacean populations has mainly focused on physiological adaptation mechanisms, such as development of cuticular pigmentation in cladocerans (melanin) $[5,6]$ and diet dependent carotenoid pigmentation, in copepods $[7,8]$. Less well documented are zooplankton reproductive traits and their importance as survival strategies through time. Life-cycles of high mountain zooplankton taxa are characterized by cyclical parthenogenesis, where a shift from parthenogenetic to sexual reproduction occurs at the end of the ice-free period leading to production of diapausing eggs (embryos at early developmental stages). These stages are capable of surviving the harsh seasons and under the ice cover, securing recruitment of individuals into the population during the ice-free period $[9,10]$.

The production of diapausing eggs with delayed development (undergoing diapause or dormancy) can be regarded as a mechanism through which taxa maintain their genetic reservoirs-buffering the high risk of extinction to which their populations are exposed [11-15]. Evaluating the "egg bank" potential allows us to estimate the vulnerability of different taxa to extinction and the risk of 
biodiversity loss in these environments. The dormant egg bank can in fact influence the rate and the direction of population, community, and ecosystem response to climate change [12,14,15]. Under global environmental changes, the frequency of extreme conditions will likely increase and species with prolonged diapause will be able to survive extreme years of no recruitment, whereas species lacking an egg bank will not. An altered environment may change species having poor recruitment and even which species produce an egg bank, through effects on thermal diapause cues [16].

Information on remote high mountains environments is usually scant, limited in time and space, and even a list of taxa from contemporary samples is generally incomplete as plurennial surveys can be rarely accomplished. To this aim of investigating spatial and temporal variability in biodiversity and time changes, integration of paleo- and neo-limnological approaches is very useful. Analyses of sediment cores allow for reconstructing long-term changes in biodiversity of biotic communities along with changes in the environment, allowing for reconstructing changes in climate and in different types of human impacts, such as long distance transport of pollutants.

In this study, we trace long-term changes in abundance of diapausing eggs in two small lakes, LCN10 and LCN70, located in the highest mountains of the world. Diapausing eggs were extracted from two short sediment cores representing different stages of the lake life history and through different climatic conditions. Abundance and viability of diapausing eggs in the sediments are crucial for complementing contemporary biodiversity estimates with potential biodiversity. Consistency of the active egg bank in the two lakes was estimated by hatching diapausing eggs recovered from the sediment cores under controlled laboratory conditions. The aim was to understand risk of loss of endemic species and vulnerability of different taxa to impact of perturbations in these fragile environments, in which impact of climate change and of anthropogenic activities is high.

Our study was conceived in the framework of an extensive multiannual study aimed at characterizing lakes in the Sagarmatha National Park, Nepal. Both water samples and sediment cores were collected during fifteen limnological surveys carried out in the period 1992-2011. Of the 120 cataloged lakes in the region, ca. 70 were characterized for hydrochemistry, 40 of which were analyzed for plankton and benthos, providing taxonomic and biodiversity estimates in different years [17]. Subfossil Cladocera remains also allowed for understanding changes in biodiversity during different climatic phases [18].

\section{Study Sites}

LCN10 and LCN70 are located in the upper Khumbu Valley (Table 1; Figure 1), in the Nepalese Himalayas $[19,20]$. They are small and shallow lakes, with an ice-covered period of 9-10 months and a high transparency during the open water phase. LCN10 receives water primarily from LCN9 located upstream and from snowfields, while LCN70, classified as a temporary lake by Löffler [21], receives water only from snowfields. Both sites are part of the 40 lakes in which plankton has been studied [22,23] in the framework of the Ev-K2-CNR project [24] developed in collaboration with the Nepal Academy of Science and Technology (NAST). Previous information on taxonomy, reporting endemic taxa, was provided by Löffler [21,25] as a result of an extensive sampling campaign in the Khumbu Valley. In previous studies, zooplankton samples were collected with plankton nets $(126 \mu \mathrm{m}$ mesh size in 1993 and 1994; $50 \mu \mathrm{m}$ mesh size in 1997 and 2004) by vertical and horizontal hauls at the deepest point and from the littoral. Samples were only qualitative, as the amount of filtered water could not be estimated. The samples were preserved in buffered $10 \%$ formaldehyde and counted to obtain estimates of relative abundance of the different taxa. LCN10, the deep lake close to the Pyramid laboratory, was visited in September-October of each sampling campaign while LCN70 was visited only in October 1994 and 1997. The list of taxa of LCN10 includes Arctodiaptomus jurisovitchi Löffler, 1968 [26], Daphnia dentifera Forbes, 1893 [27], Daphnia fusca Gurney, 1906 [28], Alona werestschagini Sinev, 1999 [29,30] and among rotifers, Ascomorpha sp. LCN70 was characterized by the prevalence of the Monogonont rotifer Hexarthra bulgarica nepalensis [31], forming dense agglomerates and bearing diapausing eggs. In this lake, only the melanic Daphnia fusca was found along with the Anostracan 
Branchinecta orientalis Sars, 1901 [22,32-34]. A few Euchlanis sp. were also reported, along with bottom dwelling Ilyocriptus acutifrons Sars, 1862 (Cladocera Mactrothricidae) and a few Harpaticoidae of the genus Maraenobiotus sp. [35]. However, given the restricted number of samples, the sampling method and the mesh size, the list of taxa from zooplankton samples is far from exhaustive. The Ev-K2-CNR Pyramid laboratory located in the region at $5050 \mathrm{~m}$ a.s.l. gave technical and logistical support for the investigations, allowing for sampling some lakes in different years between 1992 and 2011. Seasonal hydrochemistry analyses and experiments in lakes closer to the laboratory, a detailed description of the morphometry and the chemistry of lakes and the traits of their catchment basin is reported in Lami and Giussani [17]. Besides, paleolimnological and paleoclimatic reconstructions were investigated in LCN10 and LCN70 [36,37]. The region is characterized by a cold and dry climate with monthly precipitation lower than $200 \mathrm{~mm}$. Monthly mean temperatures range between $-7^{\circ} \mathrm{C}$ (December) and $5{ }^{\circ} \mathrm{C}$ (June).

Table 1. Geographic coordinates and principal morphometric characteristics of the studied lakes.

\begin{tabular}{ccc}
\hline & LCN10 & LCN70 \\
\hline Latitude & $27^{\circ} 57^{\prime} 45^{\prime \prime} \mathrm{N}$ & $27^{\circ} 53^{\prime} 36^{\prime \prime} \mathrm{N}$ \\
Longitude & $86^{\circ} 48^{\prime} 56^{\prime \prime} \mathrm{E}$ & $86^{\circ} 46^{\prime} 26^{\prime \prime} \mathrm{E}$ \\
Altitude & $5067 \mathrm{~m}$ & $4830 \mathrm{~m}$ \\
Area & $1.67 \mathrm{ha}$ & $0.63 \mathrm{ha}$ \\
Maximum depth & $14.8 \mathrm{~m}$ & $2 \mathrm{~m}$ \\
\hline
\end{tabular}

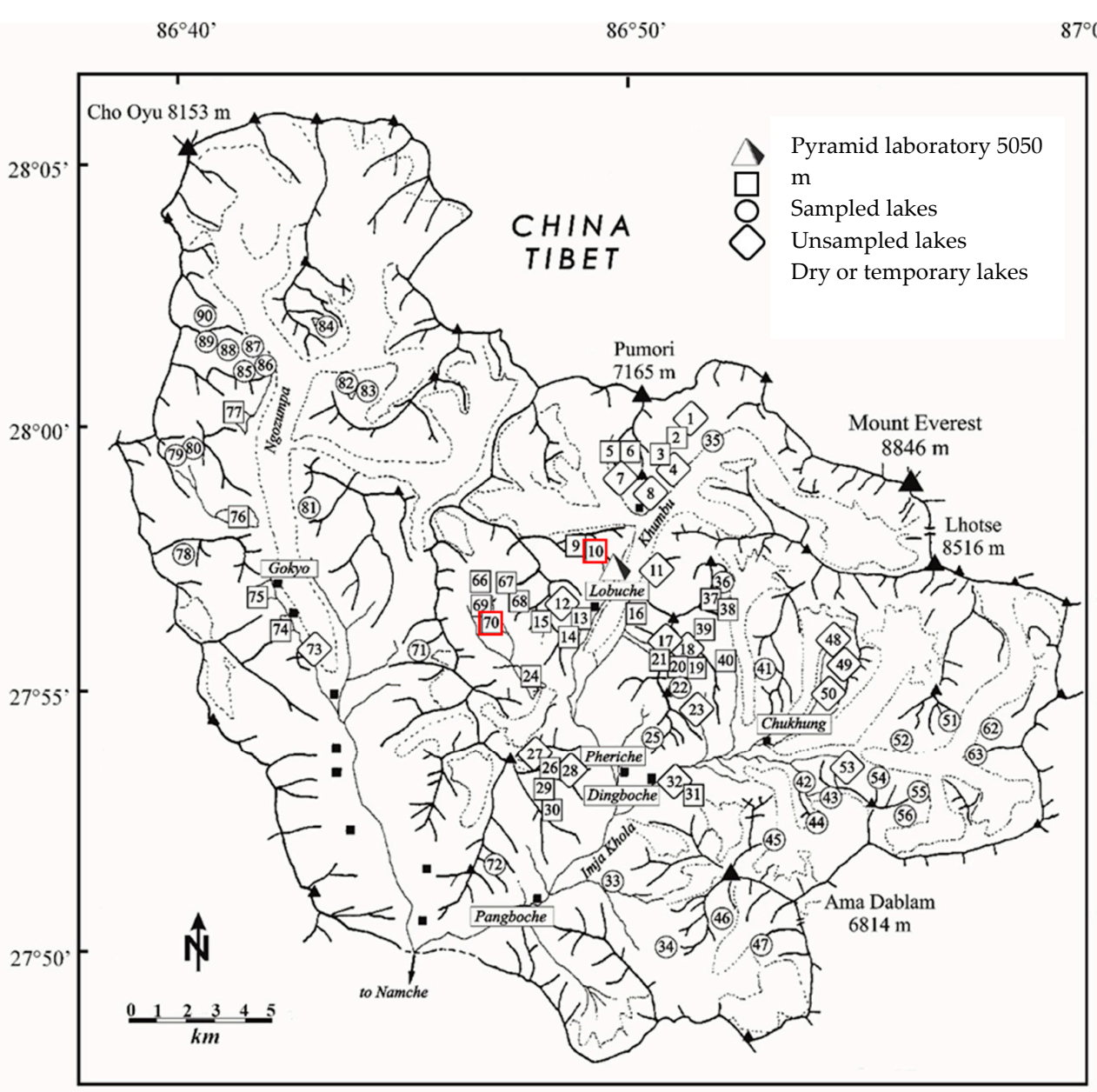

Figure 1. A map of the Khumbu and Imja Khola catchment within the Sagarmatha National Park, Nepal in which are highlighted all lakes sampled in the framework of the EV-K2-CNR project since 1987 (G.A. Tartari, pers. comm.). Black triangles refer the mountain peaks; black squares refer to localities. Red squares highlight the study sites. 


\section{Materials and Methods}

A short sediment core (04/1, $26 \mathrm{~cm}$ in length) was collected near the deepest zone of LCN10 in 2004 using a gravity corer (with $6 \mathrm{~cm}$ diameter Plexiglas tube). The age-depth model was established by correlation with a previous core $02 / 3$, dated by ${ }^{14} \mathrm{C}$ method. A detailed description is provided in Lami et al. [37]. About 200 years were represented in the topmost six-centimeter sections of the core (resulting in a sedimentation rate of $0.03 \mathrm{~cm} \mathrm{y}^{-1}$ ), and the deepest section was dated as corresponding to ca. $900 \mathrm{CE}$. The topmost $5 \mathrm{~cm}$ were sliced into sections of $1 \mathrm{~cm}$, while for the remaining core a section of $1 \mathrm{~cm}$ was taken every $5 \mathrm{~cm}$. In total, nine subsamples were extracted from the core.

Sediment samples were stored in the dark at $4{ }^{\circ} \mathrm{C}$ until microscopic analysis, in order to preserve the material and stimulate subsequent hatching [38]. All the diapausing eggs' cases found in the sediment core sections were counted, including those which, being open, were empty. The latter may indicate changes in recruitment from diapausing eggs over time. Taxonomic identification was performed, comparing images of rotifer diapausing eggs cases, which are often species-specific [39], to photographic material from previous studies [23,40] and on the basis of a guide on rotifers' diapausing eggs [41], while Anostraca diapausing eggs was based on a study [35] and literature [42-44]. Diapausing eggs were extracted following the sugar flotation method [45] modified for rotifer diapausing eggs by Garcia-Roger [46]. Taxonomic identification, counting, measurements and sorting of ephippia and rotifer diapausing egg cases were performed using a Zeiss Stemi 2000-C microscope (Carl Zeiss ${ }^{\mathrm{TM}}$, Oberkochen, Germany), equipped with software for image analysis (Image-Pro Express 5.1 (Media Cybernetics Inc., Silver Spring, USA)). The presence of eggs in dark ephippia was verified only after viability experiments, as opening ephippia cases prior to hatching might have damaged the eggs. Extracted ephippia and rotifer diapausing egg cases were individually transferred into multiwell plates (with well oxygenated culture medium of $4 \mathrm{~mL}$ oligomineral water) and stored in a thermostatic cell at $17^{\circ} \mathrm{C}$, with light intensity of about $50 \times 10^{3}$ Lux and L:D photoperiod of 16:8 h, reproducing summer environmental conditions. Every 24 hours we recorded hatchlings and renewed the culture medium.

Ephippia and diapausing egg cases from LCN70 were extracted from a sediment core collected in October 1994 (core 94/2) with a gravity corer (of $6 \mathrm{~cm}$ diameter Plexiglas tube) in the deepest zone of the lake. The core, $11.5 \mathrm{~cm}$ in length, was cut longitudinally and sectioned into $2-1.5 \mathrm{~cm}$ slices. Chronology had been established by ${ }^{210} \mathrm{~Pb}$; sedimentation rate was $0.1 \mathrm{~cm} \mathrm{y}^{-1}$ in the topmost $6 \mathrm{~cm}$ and $0.02 \mathrm{~cm} \mathrm{y}^{-1}$ between 6 and $12 \mathrm{~cm} \mathrm{[36].}$

No attempt was made to hatch cysts of the Anostracan Branchinecta orientalis.

Duration of incubation was 21 days. Eggs that did not hatch during this time period were considered as unviable.

\section{Results}

The analysis of Cladocera ephippia in core LCN10 04/1 sections revealed periods during which only one subgenus was present and periods during which both Daphnia (Ctenodaphnia) and Daphnia (Daphnia) coexisted. In particular, in sections 3-4 cm and 4-5 cm only D. (Ctenodaphnia) ephippia were present, while in the topmost section only D. (Daphnia) ephippia were found (Figure 2A). As expected from previous studies on this environment, the few ephippia found in the superficial section belonged exclusively to a $D$. (Daphnia). Contemporary zooplankton samples had identified the species as Daphnia dentifera [47]. D. (Ctenodaphnia) ephippia were of the melanic species of the region.

Apart from the deepest section, ephippia were much more abundant from 2 to $5 \mathrm{~cm}$ sections, while in sections 10-11, 1-2 and 0-1 cm, their abundance was low. The highest abundance of D. (Ctenodaphnia) ephippia $\left(12,385 \mathrm{~m}^{-2}\right)$ was found in the section $4-5 \mathrm{~cm}$ corresponding to ca. $1800 \mathrm{CE}$; a second peak was detected in the section 2-3 cm where both D. (Ctenodaphnia) and D. (Daphnia) ephippia were found (1415 ephippia $\mathrm{m}^{-2}$ and 7431 ephippia $\mathrm{m}^{-2}$, respectively). The two Daphnia species co-occurred also in sections 10-11 and 1-2 cm. Ephippia were lacking from deeper sections $(15-26 \mathrm{~cm})$ of the core. 
After 21 days of incubation, no hatchlings were recovered from the ephippia extracted from core LCN10 04/1. Opening and inspection of their content revealed that ephippia cases were either empty or with only one egg which we classified as nonviable.

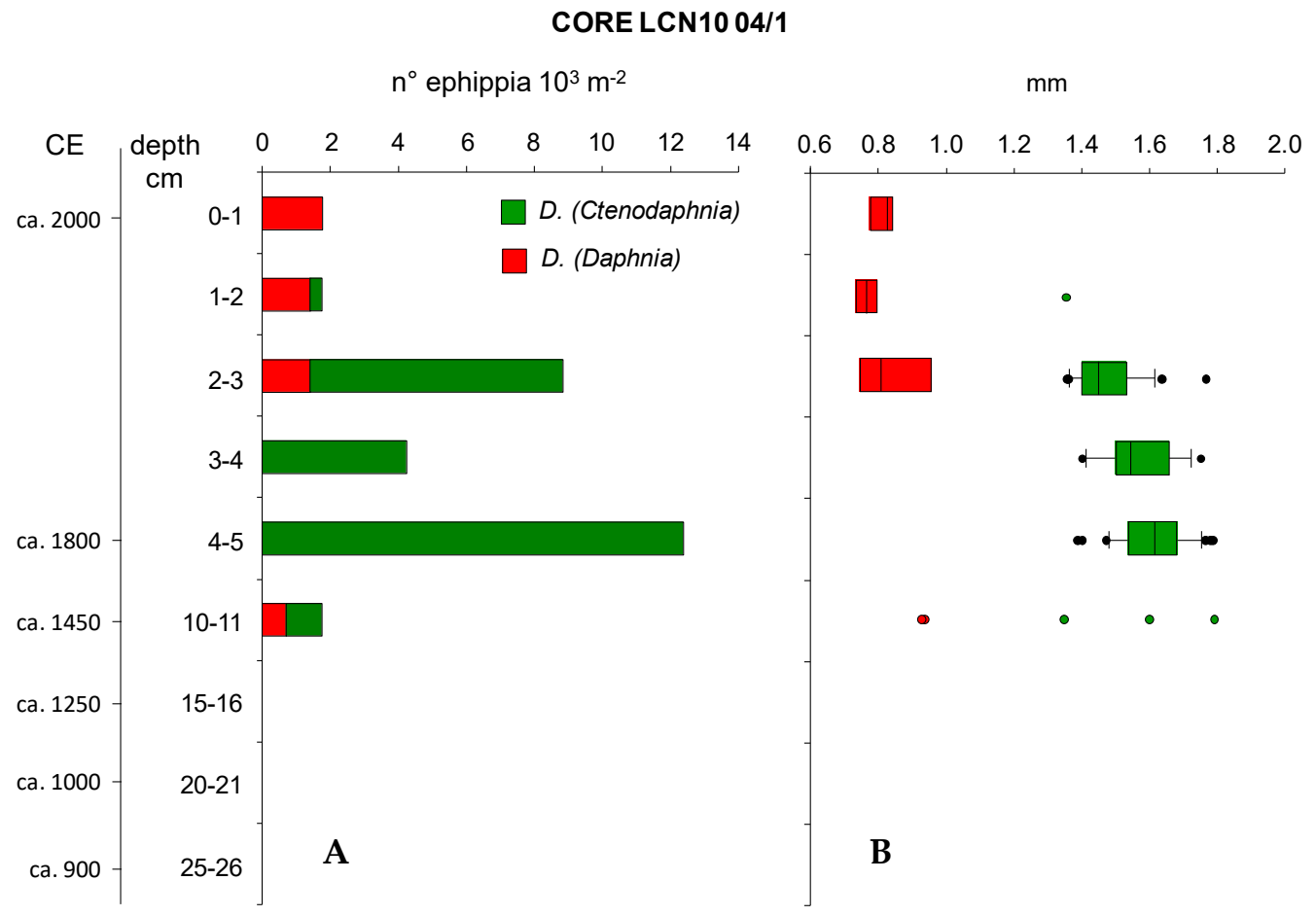

Figure 2. Abundance of ephippia in the analyzed sections of the sediment core 04/1 of LCN10 (A) and range of variation of their length (B). Vertical lines represent median values while horizontal whiskers represent the 95th percentile.

The two types of ephippia had different sizes (lengths), with those of D. (Daphnia) always smaller than those of $D$. (Ctenodaphnia). The latter decreased in size between the 3-5 and 2-3 cm sections and, in the latter section, co-occurred with those of D. (Daphnia). D. (Daphnia) ephippia at $2-3 \mathrm{~cm}$ section were in a relatively large range of sizes, along with smaller $D$. (Ctenodaphnia) ephippia size. Five ephippia in total were found in the 10-11 cm section, corresponding to ca. $1450 \mathrm{CE}$; two were from D. (Daphnia) and their length was $0.9 \mathrm{~mm}$, corresponding to the largest value of the $2 \mathrm{~cm}$ section. The other three pertained to D. (Ctenodaphnia), and their range of size did not differ from those detected in upper sediment sections. The relatively small size of the only $D$. (Ctenodaphnia) ephippium in section 1-2 cm (1.35 mm) seems to confirm the trend towards decreasing size observed between deeper and more surficial sections of the sediment core. The decrease in size of $D$. (Ctenodaphnia) ephippia in recent times was statistically significant $(\mathrm{F}=11.803, p<0.001$; Figure $2 \mathrm{~B})$. In particular, mean ephippia length was statistically different between sections $4-5$ and $2-3 \mathrm{~cm}(t=4.855, p<0.001$; Table 2$)$ and between sections $3-4$ and $2-3 \mathrm{~cm}$ $(t=2.467, p<0.016)$, but the difference between sections $4-5$ and 3-4 $\mathrm{cm}$ was nonsignificant (Table 2). Changes in size of D. (Daphnia) ephippia in different sections of the core were not statistically significant.

Table 2. Results of all pairwise multiple comparison procedures (Holm-Sidak method, overall significance level $=0.05)$ on size of $D$. (Ctenodaphnia) ephippia extracted from sediment core LCN10 04/1. Significant comparisons are highlighted in bold.

\begin{tabular}{cccc}
\hline Comparison & Difference of Means & $\boldsymbol{t}$ & Unadjusted $\boldsymbol{p}$ \\
\hline $4-5 \mathrm{~cm}$ vs. $2-3 \mathrm{~cm}$ & 135.724 & 4.855 & $<\mathbf{0 . 0 0 1}$ \\
$3-4 \mathrm{~cm}$ vs. $2-3 \mathrm{~cm}$ & 90.405 & 2.467 & $\mathbf{0 . 0 1 6}$ \\
$4-5 \mathrm{~cm}$ vs. $3-4 \mathrm{~cm}$ & 45.319 & 1.338 & 0.186 \\
\hline
\end{tabular}


Microscopical analysis of qualitative planktonic samples taken in LCN70 in 1994 revealed that both crustaceans and rotifers were present. Rotifers dominated in terms of numbers, the most common taxon being Hexarthra bulgarica nepalensis in lakes of the region [25,31]. The sample was very rich in rotifer eggs (Figure 3), with young and ovigerous females forming dense agglomerates on detritus and filamentous green algae. Few Euchlanis sp. specimens were also found [35].
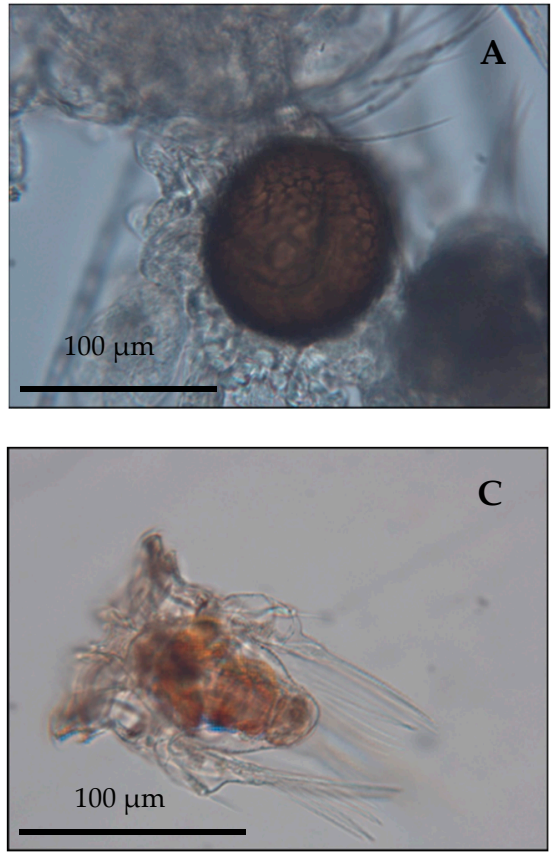
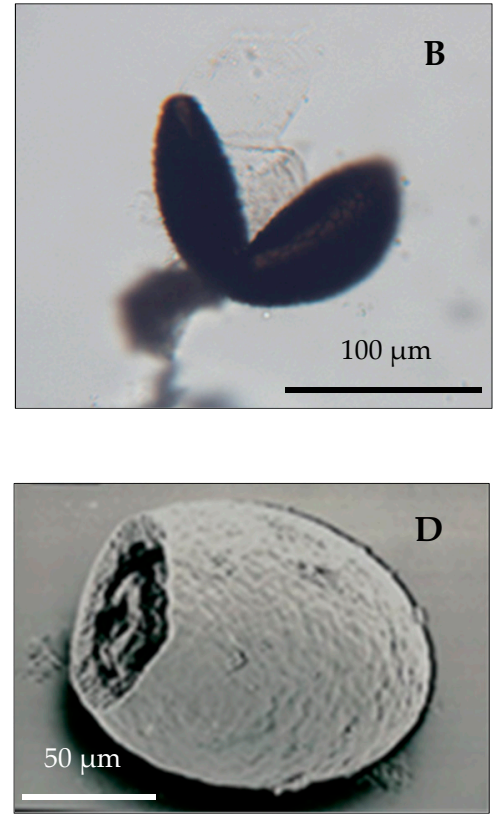

Figure 3. (A) Hexarthra bulgarica nepalensis from a plankton sample of LCN70 carrying a diapausing egg; (B) Hatching of a diapausing egg of Hexarthra bulgarica nepalensis recovered from sediment core LCN70 94/2; (C) Newborn of Hexarthra bulgarica nepalensis hatched from the diapausing egg; (D) SEM image of a Brachionus sp. open egg case recovered from sediment core LCN70 94/2.

The profile of core LCN70 94/2 (Figure 4) shows the presence of diapausing eggs of three Rotifera taxa in all the sections: the dominant Hexarthra bulgarica nepalensis and, in low abundance, Brachionus of two morphotypes as reported in Sudzuki [48] and Piscia et al. [49]. The latter two were not found in the zooplankton samples. Hexarthra diapausing eggs were abundant in all sections but tended to increase in deeper sections of the core, with a peak of $30.4 \times 10^{6} \mathrm{~m}^{-2}$ at the $8-10 \mathrm{~cm}$ section. They were between $1 \%$ and $2.5 \%$ of the total resting eggs found between the 10-11.5 and $6 \mathrm{~cm}$ sections and represented $23 \%$ and $15 \%$ of the total abundance at the 2 and at $4-6 \mathrm{~cm}$ sections, respectively. Cladocera ephippia of $D$. (Ctenodaphnia) and of Alona werestschagini, gradually increased from bottom to top layers of the sediment core and were 4.5 times more abundant in the upper $2 \mathrm{~cm}$ section than in the deepest one (10-11.5 cm). Anostracan cysts were also found to vary in abundance $\left(\mathrm{min}=1.8 \times 10^{5} \mathrm{cysts}^{-2}\right.$; $\max =5.1 \times 10^{5}$ cysts $\mathrm{m}^{-2}$ ). Brachionus resting egg cases were all open, therefore revealing that diapausing eggs produced might serve as seasonal recruitment of the species at the end of the ice cover phase. No attempt was made of hatching Anostracan cysts, as we had no indication of conditions for promoting their hatching.

Only Hexarthra diapausing eggs from the topmost $2 \mathrm{~cm}$ were still viable, with a high rate of hatching (63.6\%). Given the estimated mean sedimentation rate of $0.06 \mathrm{~cm} \mathrm{y}^{-1}$ [36], diapausing eggs in this section were deposited in a timeframe of ca. 33 years before date of collection of the core. Individual hatching timing varied between 4 and 7 days. 
CORE LCN70 94/2

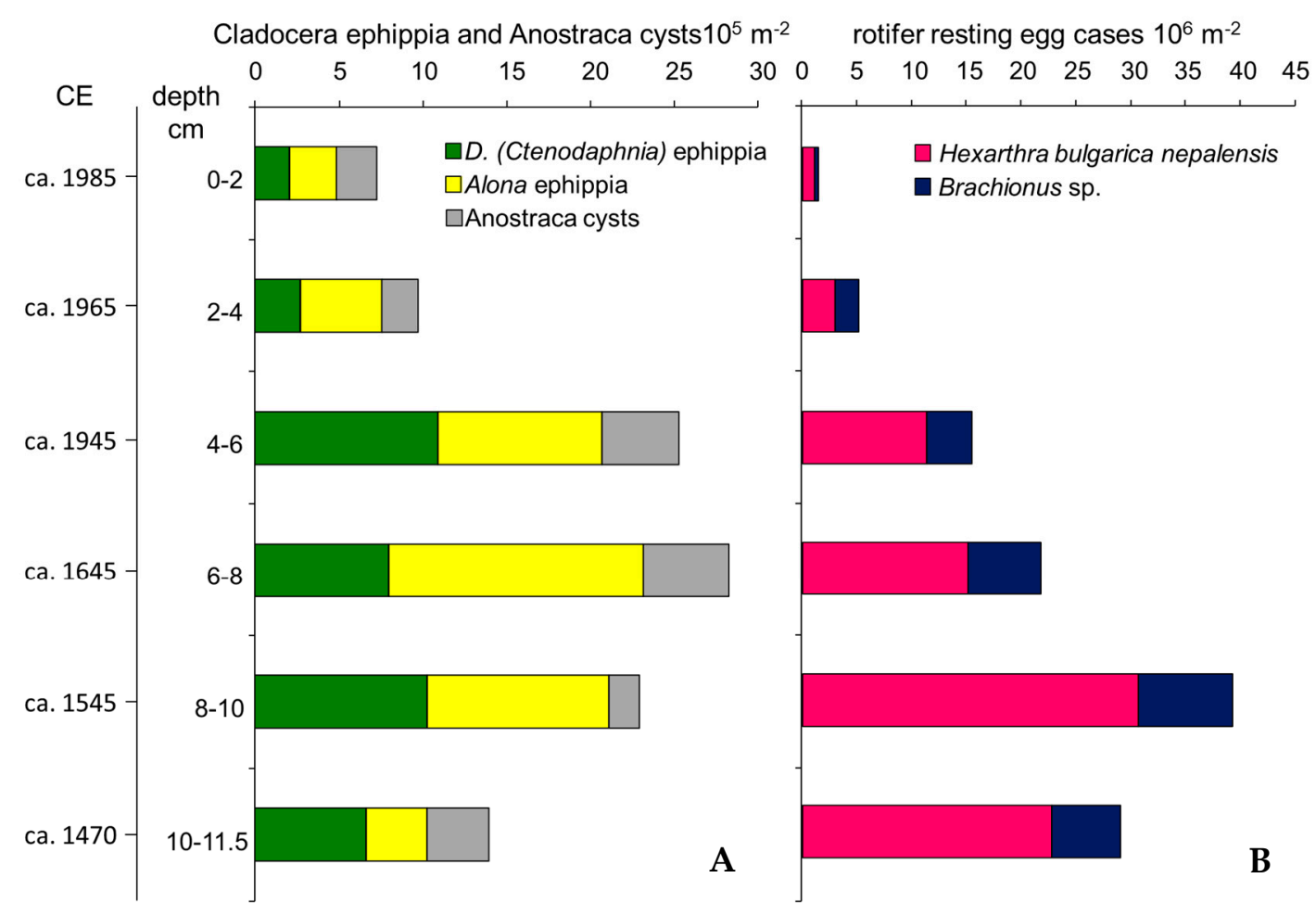

Figure 4. Abundance of Cladocera ephippia and Anostraca cysts (A) and rotifer resting eggs (B) recovered from sediment core LCN70 94/2.

\section{Discussion and Conclusions}

The presence of diapausing eggs in different sections of the two sediment cores confirmed that their production is a fundamental survival strategy in high-altitude lakes. The accumulation in sediments of diapausing eggs of different species, generations and genotypes, represents a potential reserve of biodiversity $[12,16]$, which buffers the consequent extinction risk from anthropogenic impacts and makes the population resilient to the settlement of invasive species [50,51]. Organisms able to survive in extreme environments, such as LCN10 and LCN70, belong to a small number of highly specialized species; nevertheless, the reservoir of diapausing eggs in the sediments was of the same order of size $\left(10^{3}-10^{5}\right.$ eggs per $\left.\mathrm{m}^{-2}\right)$ of those reported from less remote environments [16].

Zooplankton can produce different types of diapausing eggs: from embryos at early developmental stages of monogonont rotifers, Branchiopods and Calanoid Copepods, to advanced larval stages (Cyclopoid Copepods) and finally to adults of Harparcticoids and Bdelloid rotifers [16]. In previous studies, microscopic analysis of contemporary (plankton) samples revealed that Rotifera, Cladocera and Anostraca produced diapausing eggs at the end of the ice-free period [23,35]. Anostracan cysts recovered from sediments of LCN70 were of the species Branchinecta orientalis previous found in LCN70 and LCN30 zooplankton samples, in which the presence of diapausing eggs was also reported [35]. Among cladocerans, we found ephippia of the endemic Alona werestschagini in LCN70, D. (Daphnia) ephippia in LCN10, and D. (Ctenodaphnia) ephippia in both LCN70 and LCN10. In LCN10, in particular, an alternation in the occurrence of D. (Daphnia) and D. (Ctenodaphnia) ephippia was conspicuous and a co-occurrence of the two in the transition periods was observed. In a previous investigation, the presence of melanic D. (Ctenodaphnia) and pale D. (Daphnia) was reported [52]. Ephippia of the former were dark because of cuticular pigmentation (melanic) while those of the latter were transparent. The two also differed in size and morphology; ephippia morphology is in fact a diagnostic trait for distinguishing between Daphnia of the D. (Ctenodaphnia) type and those of the D. (Daphnia) type. The former belong to an ancestral type clearly separated from the other during the phylogeny ca. 200 million years ago [53]. 
Ephippia isolated from the surface layers of the sediment core indicate the substitution in recent times of the subgenus $D$. (Ctenodaphnia) with the subgenus $D$. (Daphnia) in agreement with plankton samples previously analyzed [23]. As suggested by Nevalainen et al. [18], the presence of D. (Ctenodaphnia) ephippia in the sediment core of LCN10 could be related to phases of enhanced connectivity with LCN9, the source of a cascade system in which D. (Ctenodaphnia) is permanent. Such changes in connectivity may in turn, be related to glacial advance or retreat driven by climate change [36]. Ephippia size is positively correlated with Daphnia body size, larger females producing larger ephippia resulting in larger neonates [54,55]. Such correspondence is the basis for reconstructing changes in Daphnia body size with changes in the environment [56]. In fishless, high mountain lakes, a wide range of Daphnia size (reconstructed from fossils, such as postabdomens, head shields, mandibles and, of course, from ephippia [52,57]) is regarded as indicative of a longer growing season, i.e., a longer ice-free season, securing a larger number of molts during the parthenogenetic phase which precedes the appearance of males and ephippial females at the end of the growing season [58,59]. In a study on LCN40, the substitution of the melanic D. (Ctenodaphnia) by the pale Daphnia dentifera in the most recent period was interpreted as related to changes in climate, with an increase in precipitation resulting in increase of dissolved organic carbon. In the case of a sediment core with low accumulation rates, however, multiple seasons in variable numbers are integrated in a $1 \mathrm{~cm}$ section during different time periods. Results of hatching experiments indicate that ephippial eggs recovered from the sediments of both lakes were nonviable, thus suggesting that an active egg bank is lacking for this important component of the zooplankton population. The apparent lack of a permanent Daphnia egg bank has been reported also from other alpine lakes (e.g., in D. umbra from a lake in southern Norway [60] and from Lake Paione Inferiore in the central Alps [58,61]. Ephippia bearing only one egg (i.e., lacking the bilocular structure typical of Daphnia ephippia [58]) or having only one diapausing egg left, are often reported as nonviable, also in the case of lakes in temperate regions [62]. As suggested in the case of lakes in the Alps forming a cascade system, we might hypothesize that the Himalayan upper Lake Piramide Superiore might represent the biotic reservoir for D. (Ctenodaphnia) fusca, as suggested in previous studies [33].

Daphnia is an important member of pond and lake systems in the Himalayas and Tibet [63-66]. Most lakes of this region were sampled during the 1960s by Löffler [21], who reported the presence of melanic Daphnia tibetana Sars, 1903 [63], endemic to the region, and pale Daphnia longispina Müller, 1776 [67] (classified as var. aspina by Werestschagin [30] because of the lack of a carapace spine at the adult stage). The former swims during the day in bottom waters and the latter apparently is restricted to lakes with limited transparency. Such distinction between transparent, "D. (Ctenodaphnia) lakes" and turbid "D. (Daphnia) lakes" was not confirmed by multiannual studies and by sediment core analyses. Our results on ephippia abundance in core 04/1 of LCN10 therefore represent a further evidence of co-occurrence of the two Daphnia species in lakes of the region. Co-occurrence of the large, melanic D. (Ctenodaphnia) and the smaller, transparent Daphnia dentifera in LCN10, is likely enhanced by different habitats: while the former is usually found swimming near the littoral, the latter tends to swim in deeper water, minimizing effects of UV damage. Our observation confirms what was reported by Löffler [21], who found the melanic Daphnia swimming in the littoral and the pale one swimming in deeper lakes and/or in turbid ones [68]. Largely differing in size, the two species might be regarded as able to feed on different food particles. In a very interesting and pioneer study, however, Geller and Müller [69] demonstrated that, while the distances between the setulae of filtering combs increase with individual body length in different Cladocera taxa, they do not increase with body length in Daphnia magna, a D. (Ctenodaphnia) species. Sharing the same food particle size, therefore, might result in a strong competition between the two Daphnia species; literature suggests that the larger one would be favored, being able to grow and reproduce at lower food concentrations [70]. Therefore, the fact that the two tend to live in different habitats appears as the most reasonable explanation.

Since the first studies carried out during the Yale North India expedition [66] of 1932-1933, endemic populations were reported from lakes in the Khumbu Region of the Himalayas, particularly among 
the zooplankton: Arctodiaptomus jurisovitchi [19] and Daphnia tibetana. Among monogonont rotifers, Hexarthra bulgarica nepalensis [31] were described. Hexarthra bulgarica has been reported from several high altitude lakes: the Rila Mountains, Bulgaria [71], the Italian Alps [72,73], the Himalayas [74], the Khumbu area (East Nepal) in lakes within the subnival belt [21,25], the Rocky Mountains (Grouse Lake, Alberta, Canada) [31], the Andes [75-77] and the Sierra Nevada [78].

The taxonomy of the melanic D. (Ctenodaphnia) from this region is problematical, largely because incomplete descriptions have been published to date. Originally, three species were identified: Daphnia pamirensis Rylov, 1930 [64], Daphnia fusca and Daphnia tibetana (first described as Daphniopsis tibetana). These species have been synonymized in every pairwise combination, or all three merged in one species, over the last century [65,79]. In his Daphnia taxonomic revision, Benzie [80] synonymized the genus Daphniopsis with the genus Daphnia, and D. pamirensis with D. fusca. He also synonymized Daphnia specimens from the Khumbu Region in Nepalese Himalayas, referred to as D. tibetana by Löffler [21] and as D. himalaya by Manca et al. [33]. More recently, a detailed analysis and taxonomic revision of diagnostic traits of the four D. (Ctenodaphnia) species (D. tibetana, D. fusca, D. pamirensis and D. himalaya) from their original sites (Kyrgyzstan, Gokyo and Khumbu, Nepal), revealed that morphology of populations of D. fusca, D. pamirensis and D. himalaya did not substantially differ from each other [47]. Results on morphology were also confirmed by genetic analyses (based on three mitochondrial genes, 12S, 16S COI). According to the latter, Himalayan and Tian Shan populations are conspecific, while $D$. tibetana clearly differs from the other two. The latter belongs to a wider group of D. (Ctenodaphnia) species that include D. atkinsoni Baird, 1859 [81] and D. mediterranea Alonso, 1985 [82] complexes as well as D. fusca. While D. tibetana and D. fusca are two valid, well differentiated but distantly related species, $D$. pamirensis and $D$. himalaya are younger synonyms of $D$. fusca. Populations of D. fusca so far occur only in high mountain glacial lakes, while D. tibetana inhabits saline lakes of Central Asian mountain ranges and high altitude plateau. Molecular systematics of the non-pigmented D. gr. longispina, presenting phylogenetic analyses for individuals collected from the Himalaya (Nepal) and the Pamir (Tajikistan) mountain ranges [47] recently suggested that populations from Nepalese Himalayas actually constitute a lineage within the D. dentifera clade. Daphnia from Lake Rangkul (Tajikistan) pertained to $D$. longispina clade. Results suggest that the two morphotypes represented two different species, among the most widespread ones in the D. longispina complex. Each species was confirmed genetically in at least two biogeographic regions (Palearctic and Holarctic in case of D. dentifera; [83] and Palearctic and Ethiopian in case of D. longispina [84]). According to these results, distribution of both species is therefore extended: the Himalayan LCN10 represents not only the westernmost, but also the highest locality reported for D. dentifera. Similarly, Lake Rangkul is the southeastern most and also the highest known locality for D. longispina, as evidenced by molecular data. A recent study on Daphnia of the Tibetan Plateau based on molecular analysis (COI gene) revealed a higher species richness with respect to those described in the past, however six of the taxonomic units identified by DNA analysis agreed very well to classical taxonomy descriptions [85].

In LCN70, Rotifera dormancy does not seem to persist over multiple seasons, except for the species Hexarthra bulgarica nepalensis. The relatively high numbers of Hexarthra diapausing eggs' cases may be indicative of a high production of diapausing eggs is this lake. In rotifers, the ability to produce diapausing eggs varies from species to species, and not necessarily with environmental conditions [86]. Differently from most Monogononta, Hexarthra stem females can in turn be mictic in temporary ponds from Texas [87]. Mictic females tend to appear very early in the season in lakes of the Sierra Nevada [78] and in temporary ponds of the Chihuahuan desert [87]. Fertilized eggs in dried sediment probably regularly hatch in large numbers soon after flooding in LCN70. They hatch during a short period that marks the beginning of population growth. The timing of this hatching period could be controlled by temperature at the sediment surface, by physical factors that promote resuspension of diapausing eggs into an oxygenated and illuminated water and by biotic factors [88-91].

Our results indicate that some of these diapausing eggs remain unhatched in their egg cases and preserve well in the sediments deposited at the bottom of LCN70, year after year, forming an 
active egg bank [92]. If the eggs are buried in the sediments, their ability to hatch probably depends on physical and biological processes that mix the sediments and bring them to the surface where they can experience hatching cues. Sediment mixing is more pronounced in shallow waters, and therefore, buried diapausing eggs should have a greater chance of hatching there [68]. In the Himalayan temporary lake studied, during the ice-free period, the water level is subject to wide fluctuations and the life cycle may start after the summer monsoon inundation provides a hatching environment with well-oxygenated water and light. Changes in the proportion of diapausing eggs in different sections of the core might therefore also reflect changes in environmental conditions related to the monsoon.

Viability tests revealed that $64 \%$ of Hexarthra diapausing eggs of the uppermost two centimeters of the sediment core were able to hatch. This result is in agreement with previous studies which reported a range of hatching success between 10\% and 88\% [51,93-95]. Given the low sedimentation rate of this lake, the deposition time of diapausing eggs spans over three decades, thus the large variation of hatching time we observed (between 4 and 7 days) may reflect differences in age of the eggs. Consistent with our results, viable zooplankton diapausing eggs are recorded in the upper 4-6 cm of sediments [49,92,96-101]. Differences between environments can be related not only to differences in sedimentation rates but also to differences in the mortality rates of dormant stages, that can range between $1 \% \mathrm{y}^{-1}$ and $64 \% \mathrm{y}^{-1}[51,100,102,103]$. In shallow ponds, as well as in our lakes, diapausing eggs are more exposed to stressing conditions (e.g., desiccation, UV radiation) than in deep lakes, and this exposure can accelerate the rate of degradation processes [100]. Nevertheless, there is evidence in literature of a high longevity, up to a maximum of 100 years [12,49,100,104,105].

Brachionus hatched resting eggs were found in the sediment core of LCN70. While reported from nearby lakes [22], Brachionus was not found in zooplankton samples of LCN70 at the time of sampling. It might have grown earlier in the season, thus leaving in the sediments the egg resting cases we found, although in lower numbers that those of Hexarthra. We expect that in these high mountain lakes, seasonal succession is similar to that already reported from similar systems in the Alps, in which small zooplankton (monogonont rotifers and immature stages of copepods) grows earlier in the season than large Daphnia [58]. The chance of finding taxa depends on time and space, and on the method used for sampling. Species rare at the time of sampling might be overlooked, and such might be the case for Brachionus in plankton samples of LCN70, which is shallow and with a rocky, heterogeneous bottom. Fossils from sediment samples generally complement taxa detection in zooplankton contemporary samples (see [18] for a list of Cladocera taxa found from the same sediment core from LPI that we used in the present study). Unfortunately, rotifers do not leave fossil remains in the sediments, and copepods are also very rarely reported, as they tend to quickly degrade. Therefore, the only chance for detecting their presence is by means of their diapausing stages. Production of diapausing eggs in copepods is rare and finding of viable diapausing eggs in lake sediments, namely of Diaptomus sanguineus Forbes, 1876 [106], as old as 350 years, is deserving of topmost journals [94]. On the contrary, production of diapausing eggs in monogonont rotifers, particularly Brachionus, forming an egg bank in the sediments is commonly reported. So, our inability to find unhatched eggs in the sediments appears contrasting with the standard very long diapause of most monogonont rotifers. Of course, it might be that, given rarity, these viable eggs were not found in our sediment samples.

In conclusion, despite producing diapausing eggs in non-negligible amounts, the Cladocera zooplankton taxa investigated in two Himalayan lakes do not seem leave a biotic reservoir in the sediments by means of viable diapausing eggs. Daphnia ephippia were in fact empty and/or with only one, nonviable egg. Similar results were obtained in previous studies, reporting that when a bilocular ephippium is partly empty, the remaining egg is usually nonviable. The presence of unilocular ephippium is also reported from high mountain lakes [58], and infertility of the ephippial egg inside is attributed to UV damage [107]. Therefore, in these high mountain lakes, the egg bank is restricted to the seasonal recruitment of active individuals into the population when the ice cover melts. The biotic reservoir of an active eggs bank seems restricted to one monogonont rotifer species, Hexarthra bulgarica 
nepalensis, whose diapausing eggs were successfully resurrected (hatched) in large numbers from relatively recent sediments.

We cannot, of course, exclude that we were truly unable to study them at best; we might simply think that, as suggested by Ruggiu et al. 1998: "Any information on freshwater organisms from a truly remote area could be intrinsically interesting" [108].

If our interpretation is true, we might be very concerned about the future of biodiversity of these lakes, so beautiful, so fragile. Given the low connections of these lakes with other aquatic environments, and their remoteness, our results highlight their high vulnerability to loss of biodiversity and of taxa which are unique and precious, super-exposed to impact of climate change and long distance transport of pollutants [109-111].

Author Contributions: Conceptualization, M.M.; investigation, M.M., R.P., S.B., A.L. and P.G.; formal analysis: R.P. and S.B.; writing—original draft preparation, M.M. and R.P.; writing-review and editing, M.M., R.P., A.L. and P.G.; visualization, funding acquisition, M.M. and A.L. All authors have read and agreed to the published version of the manuscript.

Funding: The present research was funded to M.M. by CNR RSTL (Basic research funds on special projects) $n^{\circ} 552$ on "Evolution of biodiversity and evaluation of the egg bank of aquatic organisms of remote lakes". Sampling and basic sediment core analyses were supported by funds to A.L. from CNR, Research Project on "Impact of Global Change in high elevation remote sites".

Acknowledgments: We wish to thank Simona Musazzi for helping in sampling of the sediment core of LCN10 in 2004 and G.A. Tartari for sampling the core of LCN70 in 1994. We wish to express our gratitude to the two anonymous referees: their contribution was crucial for substantially improving a previous version of the manuscript.

Conflicts of Interest: The authors declare no conflict of interest.

\section{References}

1. Battarbee, R.W.; Grytnes, J.A.; Thompson, R.; Appleby, P.G.; Catalan, J.; Korhola, A.; Birks, H.J.B.; Heegaard, E.; Lami, A. Comparing palaeolimnological and instrumental evidence of climate change for remote mountain lakes over the last 200 years. J. Paleolimnol. 2002, 28, 161-179. [CrossRef]

2. Kong, L.; Yang, X.; Kattel, G.; Anderson, N.J.; Hu, Z. The response of Cladocerans to recent environmental forcing in an Alpine Lake on the SE Tibetan Plateau. Hydrobiologia 2017, 784, 171-185. [CrossRef]

3. Catalan, J.; Ninot, J.M.; Aniz, M.M. (Eds.) High mountain conservation in a changing world. In Advances in Global Change Research; Springer International Publishing AG: Basel, Switzerland, 2017; p. 413. [CrossRef]

4. Kořínek, V.; Villalobos, L. Two South American endemic species of Daphnia from high Andean lakes. Hydrobiologia 2003, 490, 107-123. [CrossRef]

5. Herbert, P.D.N.; Emery, C.J. The adaptive significance of cuticular pigmentation in Daphnia. Funct. Ecol. 1990, 4, 703-710. [CrossRef]

6. Hessen, D.O. Competitive trade-off strategies in Arctic Daphnia linked to melanism and UV-B stress. Polar Biol. 1996, 16, 573-579. [CrossRef]

7. Ringelberg, J. Aspects of red pigmentation in zooplankton, especially copepods. In Ecology and Evolution of Zooplankton Communities; Kerfoot, W.C., Ed.; University Press of New England: Lebanon, NH, USA, 1980; pp. 91-97.

8. Moeller, R.E.; Gilroy, S.; Williamson, C.E.; Grad, G.; Sommaruga, R. Dietary acquisition of photoprotective compounds (mycosporine-like amino acids, carotenoids) and acclimation to ultraviolet radiation in a freshwater copepod. Limnol. Oceanogr. 2005, 50, 427-439. [CrossRef]

9. Cáceres, C.E. Interspecific variation in the abundance, production, and emergence of Daphnia diapausing eggs. Ecology 1998, 79, 1699-1710. [CrossRef]

10. Pérez-Martínez, C.; Barea-Arco, J.; Conde-Porcuna, J.M.; Morales-Baquero, R. Reproduction strategies of Daphnia pulicaria population in a high mountain lake of Southern Spain. Hydrobiologia 2007, 594, 75-82. [CrossRef]

11. De Stasio, B.T. The seed bank of a freshwater crustacean: Copepodology for the plant ecologist. Ecology 1989, 70, 1377-1389. [CrossRef] 
12. Hairston, N.G., Jr. Zooplankton egg banks as biotic reservoirs in changing environments. Limnol. Oceanogr. 1996, 41, 1087-1092. [CrossRef]

13. De Meester, L.; Gómez, A.; Okamura, B.; Schwenk, K. The Monopolization Hypothesis and the dispersal-gene flow paradox in aquatic organisms. Acta Oecol. 2002, 23, 121-135. [CrossRef]

14. Dupuis, A.P.; Hann, B.J. Climate change, diapause termination and zooplankton population dynamics: An experimental and modelling approach. Freshw. Biol. 2009, 54, 221-235. [CrossRef]

15. Jones, N.T.; Gilbert, B. Changing climate cues differentially alter zooplankton dormancy dynamics across latitudes. J. Anim. Ecol. 2016, 85, 559-569. [CrossRef]

16. Brendonck, L.; De Meester, L. Egg banks in freshwater zooplankton: Evolutionary and ecological archives in the sediment. In Recent Developments in Fundamental and Applied Plankton Research; Van Donk, E., Spaak, P., Boersma, M., Eds.; Kluwer Academic Publishers: Dordrecht, The Netherlands, 2003; Volume 491, pp. 65-84. [CrossRef]

17. Lami, A.; Giussani, G. (Eds.) Limnology of high altitude lakes in the Mt. Everest Region (Nepal). Mem. Ist. Ital. Idrobiol. 1998, 57, 1-235.

18. Nevalainen, L.; Lami, A.; Luoto, T.P.; Manca, M. Fossil cladoceran record from Lake Piramide Inferiore (5067 m asl) in the Nepalese Himalayas: Biogeographical and paleoecological implications. J. Limnol. 2014, 73. [CrossRef]

19. Tartari, G.A.; Panzani, P.; Adreani, L.; Ferrero, A.; De Vito, C. Lake cadastre of Khumbu Himal Region: Geographical-geological-limnological data base. Limnology of high altitude lakes in the Mt Everest Region (Nepal). Mem. Ist. Ital. Idrobiol. 1998, 57, 151-235.

20. Tartari, G.A.; Tartari, G.; Mosello, R. Water chemistry of high altitude lakes in the Khumbu and Imja Kola valleys (Nepalese Himalayas). Mem. Ist. Ital. Idrobiol. 1998, 57, 51-76.

21. Löffler, H. High altitude lakes in Mt. Everest region. Verh. Int. Ver. Limnol. 1969, 17, 373-385. [CrossRef]

22. Manca, M.; Nocentini, A.M.; Ruggiu, D.; Panzani, P.; Bonardi, M.; Cammarano, P.; Spagnuolo, T. Observations on plankton and macrobenthic fauna of some high altitude Himalayan lakes. Mem. Ist. Ital. Idrobiol. 1995, 53, 17-25.

23. Manca, M.; Ruggiu, D.; Panzani, P.; Asioli, A.; Mura, G.; Nocentini, A.M. Report on a collection of aquatic organisms from high mountain lakes in the Khumbu Valley (Nepalese Himalayas). J. Limnol. 1998, 57, 77-98.

24. Baudo, R.; Tartari, G.; Munawar, M. (Eds.) Top of the world environmental research: Mount Everest-Himalayan ecosystem. In Ecovision World Monograph Series; Schweizerbart Science Publishers: Stuttgart, Germany, 1998; pp. 1-294.

25. Daems, G.; Dumont, H.J. Rotifers from Nepal, with the description of a new species of Scaridium and a discussion of the Nepalese representatives of the genus Hexarthra. Biol. Jb. Dodonaea 1974, 42, 61-81.

26. Löffler, H. Diaptomus (Arctodiaptomus) jurisowitchi nov. spec. aus dem Khumbu-gebiet (Nepal). Khumbu Himal. 1968, 3, 9-16.

27. Forbes, S.A. A preliminary report on the aquatic invertebrate fauna of the Yellowstone National Park, Wyoming, and the Flathead Region of Montana. US Fish. Comm. Bull. 1893, 11, 207-256.

28. Gurney, R. On some freshwater Entomostraca in the collection of the Indian Museum, Calcutta. J. Asia. Soc. Bengal 1906, 2, 273-281.

29. Sinev, A.Y. Alona werestschagini sp., a new species of the genus Alona Baird, 1843 related to A. guttata Sars, 1862 (Anomopoda: Chydoridae). Arthropoda Sel. 1999, 8, 23-30.

30. Werestschagin, G. Kfaune Cladocera Kavkaza (The Caucasian Fauna of Cladocera). Raboty laboratorii zoologicheskogo kabineta Imeratorskogo Varshavskogo Universtiteta; University of Warsaw: Warsaw, Poland, 1911; pp. 1-17.

31. Dumont, H.J.; Coussement, M.; Anderson, R.S. An examination of some Hexarthra species (Rotatoria) from western Canada and Nepal. Can. J. Zool. 1978, 56, 440-445. [CrossRef]

32. Sars, G.O. Contributions to the Knowledge of the Fresh-water "Entomostraca" of South America, as Shown by Artificial Hatching from Dried Material, by GO Sars. Part II. “Copepoda-Ostracoda”. Arch. Mat. Nat. 1901, 23, 1-101.

33. Manca, M.; Martin, P.; Peñalva-Arana, D.C.; Benzie, J.A. Re-description of Daphnia (Ctenodaphnia) from lakes in the Khumbu Region, Nepalese Himalayas, with the erection of a new species, Daphnia himalaya, and a note on an intersex individual. J. Limnol. 2006, 65, 132-140. [CrossRef]

34. Manca, M.; Cammarano, P.; Spagnuolo, T. Notes on Cladocera and Copepoda from high altitude lakes in the Mount Everest Region (Nepal). Hydrobiologia 1994, 287, 225-231. [CrossRef] 
35. Manca, M.; Mura, G. On Branchinecta orientalis Sars (Anostraca) in the Himalayas. Hydrobiologia 1997, 356, 111-116. [CrossRef]

36. Lami, A.; Guilizzoni, P.; Marchetto, A.; Bettinetti, R.; Smith, D.J. Palaeolimnological evidence of environmental changes in some high altitude Himalayan lakes (Nepal). Mem. Istit. Ital. Idrobiol. 1998, 57, 130-131.

37. Lami, A.; Marchetto, A.; Musazzi, S.; Salerno, F.; Tartari, G.; Guilizzoni, P.; Rogora, M.; Tartari, G.A. Chemical and biological response of two small lakes in the Khumbu Valley, Himalayas (Nepal) to short-term variability and climatic change as detected by long-term monitoring and paleolimnological methods. Hydrobiologia 2010, 648, 189-205. [CrossRef]

38. Cousyn, C.; De Meester, L. The vertical profile of resting egg banks in natural populations of the pond-dwelling cladoceran Daphnia magna Straus. Arch. Hydrobiol. 1998, 52, 127-139.

39. Guerrero-Jiménez, G.; Ramos-Rodríguez, E.; Silva-Briano, M.; Adabache-Ortiz, A.; Conde-Porcuna, J.M. Analysis of the morphological structure of diapausing propagules as a potential tool for the identification of rotifer and cladoceran species. Hydrobiologia 2019, 847, 1-24. [CrossRef]

40. Suzduki, M. New systematical approach to the Japanese planktonic Rotatoria. Hydrobiologia 1964, 23, 1-124.

41. Koste, W. Rotatoria. Die Rädertiere Mitteleuropas (Überordnung Monogononta). In Bestimmugswerk Begründet von Max Voigt; Gebrüder Borntraeger: Stuttgart, Germany, 1978; Volume 2, p. 234.

42. Mura, G. SEM morphological survey on the egg shell in the Italian anostracans (Crustacea, Branchiopoda). Hydrobiologia 1986, 134, 273-286. [CrossRef]

43. Mura, G. SEM morphology of resting eggs in the species of the genus Branchinecta from North America. J. Crustac. Biol. 1991, 11, 432-436. [CrossRef]

44. Fugate, M. Branchinecta sandiegonensis, a new species of fairy shrimp (Crustacea: Anostraca) from western North America. Proc. Biol. Soc. Wash. 1993, 106, 296.

45. Onbe, T. Sugar flotation method for the sorting the resting eggs of marine cladocerans and copepods from sea-bottom sediment. Bull. Jpn. Soc. Sci. Fish. 1978, 44, 1411. [CrossRef]

46. García-Roger, E.M.; Carmona, M.J.; Serra, M. Deterioration patterns in diapausing egg banks of Brachionus (Müller, 1786) rotifer species. J. Exp. Mar. Biol. Ecol. 2005, 314, 149-161. [CrossRef]

47. Moest, M.; Petrusek, A.; Sommaruga, R.; Juračka, P.J.; Slusarczyk, M.; Manca, M.; Spaak, P. At the edge and on the top: Molecular identification and ecology of Daphnia dentifera and D. longispina in high-altitude Asian lakes. Hydrobiologia 2013, 715, 51-62. [CrossRef]

48. Sudzuki, M. Intraspecific variability of Brachionus plicatilis. Hydrobiologia 1987, 147, 45-47. [CrossRef]

49. Piscia, R.; Guilizzoni, P.; Fontaneto, D.; Vignati, D.A.; Appleby, P.G.; Manca, M. Dynamics of rotifer and cladoceran resting stages during copper pollution and recovery in a subalpine lake. Ann. Limnol. Int. J. Lim. 2012, 48, 151-160. [CrossRef]

50. Latta, L.C.; Fisk, D.L.; Knapp, R.A.; Pfrender, M.E. Genetic resilience of Daphnia populations following experimental removal of introduced fish. Conserv. Genet. 2010, 11, 1737-1745. [CrossRef]

51. García-Roger, E.M.; Lubzens, E.; Fontaneto, D.; Serra, M. Facing Adversity: Dormant Embryos in Rotifers. Biol. Bull. 2019, 237, 119-144. [CrossRef] [PubMed]

52. Manca, M.; Comoli, P. Reconstructing long-term changes in Daphnia's body size from subfossil remains in sediments of a small lake in the Himalayas. J. Paleol. 2004, 32, 95-107. [CrossRef]

53. Colbourne, J.K.; Hebert, P.D. The systematics of North American Daphnia (Crustacea: Anomopoda): A molecular phylogenetic approach. Philos. Trans. R. Soc. Lond. B Biol. Sci. 1996, 351, 349-360.

54. Green, J. Growth, size and reproduction in Daphnia (Crustacea: Cladocera). Proc. Zool. Soc. Lond. 1956, 126, 173-204. [CrossRef]

55. Arbačiauskas, K. Seasonal phenotypes of Daphnia: Post-diapause and directly developing offspring. J. Limnol. 2004, 63, 7-15. [CrossRef]

56. Jeppesen, E.; Jensen, J.P.; Amsinck, S.; Landkildehus, F.; Lauridsen, T.; Mitchell, S.F. Reconstructing the historical changes in Daphnia mean size and planktivorous fish abundance in lakes from the size of Daphnia ephippia in the sediment. J. Paleolimnol. 2002, 27, 133-143. [CrossRef]

57. Manca, M.; Comoli, P. Reconstructing population size structure in Cladocera by measuring their body remains. Mem. Ist. Ital. Idrobiol. 1995, 54, 61-68.

58. Cammarano, P.; Manca, M. Studies on zooplankton in two acidified high mountain lakes in the Alps. Hydrobiologia 1997, 356, 97-109. [CrossRef] 
59. Manca, M.; Comoli, P. Studies on zooplankton of Lago Paione Superiore. J. Limnol. 1999, 58, 131-135. [CrossRef]

60. Larsson, P.; Wathne, I. Swim or rest during the winter-what is best for an alpine daphnid? Arch. Hydrobiol. 2006, 167, 265-280. [CrossRef]

61. Guilizzoni, P.; Lami, A.; Manca, M.; Musazzi, S.; Marchetto, A. Palaeoenvironmental changes inferred from biological remains in short lake sediment cores from the Central Alps and Dolomites. Hydrobiologia 2006, 562,167-191. [CrossRef]

62. Marková, S.; Černý, M.; Rees, D.; Stuchlík, E. Are they still viable? Physical conditions and abundance of Daphnia pulicaria resting eggs in sediment cores from lakes in the Tatra Mountains. Biologia 2006, 61, S135-S146. [CrossRef]

63. Sars, G.O. An Account of the Crustacea of Norway, with Short Descriptions and Figures of all the Species: IV. Copepoda Calanoida; Compilation, Ed.; Bergens Museum: Bergen, Germany, 1903; Volume 171.

64. Rylov, W.M. The Fresh-Water Calanoids of the U.S.S.R. Keys to Determination of Fresh-Water Organism of the U.S.S.R. A Fresh-Water Fauna; Institute Fisheries and Science Explorations: Leningrad, Russia, 1930; pp. 1-288.

65. Wagler, E. Die Systematik und geographische Verbreitung des Genus Daphnia O.F. Müller mit besonderer Berucksichtigung des sudafrikanischen Arten. Arch. Hydrobiol. 1936, 30, 505-556.

66. Hutchinson, G. Limnological studies in Indian Tibet. Int. Rev. Gesamten Hydrobiol. 1937, 35, $134-177$. [CrossRef]

67. Müller, O.F. Zoologiæ Danicx Prodromus, seu Animalium Daniæ et Norvegiæ indigenarum characteres, nomina, et synonyma imprimis popularium; Hallageri: Copenhagen, Denmark, 1776; p. 274.

68. Manca, M.; Comoli, P.; Margaritora, F.G. An unusual type of Daphnia head shields from plankton and sediments of Himalayan lakes. J. Limnol. 1999, 58, 29-32. [CrossRef]

69. Geller, W.; Müller, H. The filtration apparatus of Cladocera: Filter mesh-sizes and their implications on food selectivity. Oecologia 1981, 49, 316-321. [CrossRef]

70. Gliwicz, Z.M. Food thresholds and body size in cladocerans. Nature 1990, 343, 638-640. [CrossRef]

71. Wiszniewski, J. Un nouveau rotifere du genre Pedalia habitant les lacs des hautes montagnes. Int. Rev. Ges. Hydrobiol. Hydrogr. 1933, 29, 229-236. [CrossRef]

72. Tonolli, V.; Tonolli, L. Osservazioni sulla biologia ed ecologia di 170 popolamenti zooplanctonici di laghi italiani de alta quota. Mem. 1st Ital. Idrobiol. 1951, 6, 53-136.

73. Ferrari, I. Notes on the dynamics of the reproductive activity of Arctodiaptomus bacillifer in high altitude alpine lakes. Boll. Zool. 1971, 38, 221-235. [CrossRef]

74. Edmondson, W.T.; Hutchinson, G.E. Report on Rotatoria. Mem. Conn. Acad. Arts Sci. 1934, 10, $153-186$.

75. Ruttner-Kolisko, A. Plankton Rotifers, biology and taxonomy. Binnengewässer 1974, 26, 146.

76. Modenutti, B.E. Summer population of Hexarthra bulgarica in a high elevation lake of south Andes. Hydrobiologia 1993, 259, 33-37. [CrossRef]

77. Zagarese, H.E.; Diaz, M.; Pedrozo, F.; Ubeda, C. Mountain lakes in northwestern Patagonia. Int. Ver. Angew. Limnol. Verh. 2000, 27, 533-538. [CrossRef]

78. Cruz-Pizarro, L.; Morales, R. Taxonomic and ecological notes on Hexarthra bulgarica from high mountain lakes and ponds in the Sierra Nevada (Spain). Hydrobiologia 1987, 147, 91-95. [CrossRef]

79. Brehm, V.; Woltereck, R. Die Daphniden der Yale-Northindia-Expedition. Int. Rev. Gesamten Hydrobiol. Hydrograp. 1939, 39, 1-19. [CrossRef]

80. Benzie, J.A. The genus Daphnia (including Daphniopsis) (anomopoda: Daphniidae). In Guides to the Identification of the Microinvertebrates of the Continental Waters of the World; Kenobi Productions: Grant Pass, OR, USA, 2005; Volume 21, pp. 1-376.

81. Baird, W. Description of some new recent Entomostraca from Nagpur, collected by the Rev. S. Hislop. Proc. Zool. Soc. Lond. 1859, 27, 231-234.

82. Alonso, M. Daphnia (Ctenodaphnia) Mediterranea: A new species of hyperhaline waters, long confused with D. (C.) Dolichocephala Sars, 1895. Hydrobiologia 1985, 128, 217-228. [CrossRef]

83. Ishida, S.; Taylor, D.J. Mature habitats associated with genetic divergence despite strong dispersal ability in an arthropod. BMC Evol. Biol. 2007, 7, 52. [CrossRef] [PubMed]

84. Petrusek, A.; Hobæk, A.; Nilssen, J.P.; Skage, M.; Černý, M.; Brede, N.; Schwenk, K. A taxonomic reappraisal of the European Daphnia longispina complex (Crustacea, Cladocera, Anomopoda). Zool. Scr. 2008, 37, 507-519. [CrossRef] 
85. Xu, L.; Lin, Q.; Xu, S.; Gu, Y.; Hou, J.; Liu, Y.; Dumont, H.J.; Han, B.P. Daphnia diversity on the Tibetan Plateau measured by DNA taxonomy. Ecol. Evol. 2018, 8, 5069-5078. [CrossRef]

86. Gilbert, J.J. Timing of diapause in monogonont rotifers: Mechanisms and strategies. In Diapause in Aquatic Invertebrates Theory and Human Use; Alekseev, V.R., de Stasio, B.T., Gilbert, J.J., Eds.; Springer: Dordrecht, Germany, 2007; pp. 11-27.

87. Schröder, T.; Howard, S.; Arroyo, M.L.; Walsh, E.J. Sexual reproduction and diapause of Hexarthra sp. (Rotifera) in short-lived ponds in the Chihuahuan Desert. Freshw. Biol. 2007, 52, 1033-1042. [CrossRef]

88. Vandekerkhove, J.; Declerck, S.; Brendonck, L.; Conde-Porcuna, J.M.; Jeppesen, E.; Meester, L.D. Hatching of cladoceran resting eggs: Temperature and photoperiod. Freshw. Biol. 2005, 50, 96-104. [CrossRef]

89. Gilbert, J.J.; Schröder, T. Rotifers from diapausing, fertilized eggs: Unique features and emergence. Limnol. Oceanogr. 2004, 49, 1341-1354. [CrossRef]

90. Gilbert, J.J. Resting-egg hatching and early population development in rotifers: A review and a hypothesis for differences between shallow and deep waters. Hydrobiologia 2017, 796, 235-243. [CrossRef]

91. Bozelli, R.L.; Tonsi, M.; Sandrini, F.; Manca, M. A Big Bang or small bangs? Effects of biotic environment on hatching. J. Limnol. 2008, 67, 100-106. [CrossRef]

92. Cáceres, C.E.; Hairston, N.G. Benthic-pelagic coupling in planktonic crustaceans: The role of the benthos. Ergeb. Limnol. 1998, 52, 163-174.

93. Marcus, N.H.; Lutz, R.; Burnett, W.; Cable, P. Age, viability, and vertical distribution of zooplankton resting eggs from an anoxic basin: Evidence of an egg bank. Limnol. Oceanogr. 1994, 39, 154-158. [CrossRef]

94. Hairston, N.G., Jr.; Van Brunt, R.A.; Kearns, C.M.; Engstrom, D.R. Age and survivorship of diapausing eggs in a sediment egg bank. Ecology 1995, 76, 1706-1711. [CrossRef]

95. Franch-Gras, L.; García-Roger, E.M.; Serra, M.; José Carmona, M. Adaptation in response to environmental unpredictability. Proc. R. Soc. Lond. B Biol. Sci. 2017, 284, 2017.0427. [CrossRef]

96. Herzig, A. Resting eggs-A significant stage in the life cycle of crustaceans Leptodora kindtii and Bythotrephes longimanus. Int. Ver. Angew. Limnol. Verh. 1985, 22, 3088-3098.

97. Carvalho, G.R.; Wolf, H.G. Resting eggs of lake-Daphnia, I. Distribution, abundance and hatching of eggs collected from various depths in lake sediments. Freshwat. Biol. 1989, 22, 459-470. [CrossRef]

98. Hairston, N.G.; Van Brunt, R.A. Diapause dynamics of two diaptomid copepod species in a large lake. Hydrobiologia 1994, 292, 209-218. [CrossRef]

99. García-Roger, E.M.; Carmona, M.J.; Serra, M. Hatching and viability of rotifer diapausing eggs collected from pond sediments. Freshw. Biol. 2006, 51, 1351-1358. [CrossRef]

100. García-Roger, E.M.; Carmona, M.J.; Serra, M. Patterns in rotifer diapausing egg banks: Density and viability. J. Exp. Mar. Biol. Ecol. 2006, 336, 198-210. [CrossRef]

101. Piscia, R.; Tabozzi, S.; Bettinetti, R.; Nevalainen, L.; Manca, M.M. Unexpected increases in rotifer resting egg abundances during the period of contamination of Lake Orta. J. Limnol. 2016, 75, 76-85. [CrossRef]

102. García-Roger, E.M.; Ortells, R. Trade-offs in rotifer diapausing egg traits: Survival, hatching, and lipid content. Hydrobiologia 2018, 805, 339-350. [CrossRef]

103. Gabaldón, C.; Serra, M.; Carmona, M.J.; Montero-Pau, J. Life-history traits, abiotic environment and coexistence: The case of two cryptic rotifer species. J. Exp. Mar. Biol. Ecol. 2015, 465, 142-152. [CrossRef]

104. King, C.E.; Serra, M. Seasonal variation as a determinant of population structure in rotifers reproducing by cyclical parthenogenesis. Hydrobiologia 1998, 387, 361-372. [CrossRef]

105. Kotani, T.; Ozaki, M.; Matsuoka, K.; Snell, T.W.; Hagiwara, A. Reproductive isolation among geographically and temporally isolated marine Brachionus strains. Hydrohiologia 2001, 446, 283-290. [CrossRef]

106. Forbes, S.A. List of Illinois Crustacea. Bull. Iii Mus. Nat. Hist. 1876, 1, 3-76.

107. Raikow, D.F.; Reid, D.F.; Blatchley, E.R., III; Jacobs, G.; Landrum, P.F. Effects of proposed physical ballast tank treatments on aquatic invertebrate resting eggs. Environ. Toxicol. Chem. Int. J. 2007, 26, 717-725. [CrossRef]

108. Ruggiu, D.; Bertoni, R.; Callieri, C.; Manca, M.; Nocentini, A. Assessment of biota in lakes form the Khumbu Valley, high Hiamalayas. In Top of the World Environmental Research: Mount Everest-Himalayan Ecosystem; Baudo, R., Tartari, G., Munawar, M., Eds.; Blackhuys Publishers: Leiden, The Netherlands, 1998; pp. 219-233.

109. Fernandez, P.; Carrera, G.; Grimalt, J. Persistent organic pollutants in remote freshwater ecosystems. Aquat. Sci. 2005, 67, 263-273. [CrossRef] 
110. Schmid, P.; Bogdal, C.; Blüthgen, N.; Anselmetti, F.S.; Zwyssig, A.; Hungerbühler, K. The missing piece: Sediment records in remote mountain lakes confirm glaciers being secondary sources of persistent organic pollutants. Environ. Sci. Technol. 2011, 45, 203-208. [CrossRef]

111. Guzzella, L.; Salerno, F.; Freppaz, M.; Roscioli, C.; Pisanello, F.; Poma, G. POP and PAH contamination in the southern slopes of Mt. Everest (Himalaya, Nepal): Long-range atmospheric transport, glacier shrinkage, or local impact of tourism? Sci. Total Environ. 2016, 544, 382-390. [CrossRef] 